\title{
Technical Efficiency of Red Rice Farming in Gunung Kidul Regency, Yogyakarta
}

\author{
Lestari Rahayu* and Ratih Hanifah \\ Department of Agribusiness, Universitas Muhammadiyah Yogyakarta, Jl. Brawijaya, Geblagan, \\ Tamantirto, Kasihan, Bantul, Daerah Istimewa Yogyakarta 55183, Indonesia
}

\begin{abstract}
Red rice is germplasm in Gunung Kidul Regency, whose territory is north, central, and south. This study aimed to analyze the factors that influence the production of red rice farming in Gunung Kidul Regency, analyze the level of technical efficiency, and the factors that influence the technical inefficiency of red rice farming in Gunung Kidul Regency. This research was conducted in Gunung Kidul Regency, which was determined purposively, in sampling 200 respondents. Data were analyzed using the Cobb-Douglas Stochastic Frontier model production function. The results showed that the variable area of land, seeds, manure, phonska fertilizer, urea fertilizer, liquid pesticides, and labor had a significant effect on the production of red rice. Technically, farmers have been efficient, with an average index of 0.837 . Meanwhile, from the five internal factors of farmers, age, formal education, farming experience, dummy zones in the north, dummy zones in the south, no effect on inefficiency
\end{abstract}

\section{Introduction}

Rice is included in food crops that are categorized as staple foods for Indonesians and countries in Asia. Rice is distinguished into three kinds of white, red, and black rice according to its color. White rice is rice that is in great demand and produced. In fact, in terms of price, red rice can also compete compared to white rice. In addition to white rice, red rice began to favor them because of its lower sugar content. The advantages of red rice are mainly in productivity and resistance to disease, production costs needed, harvest age, and ease in maintenance [1].

"Yogyakarta Special Region Province (DIY) is one of the provinces that has variations in the diversity of agricultural germplasm, namely accession of red rice germplasm" [2] According to [2], "there are several accessions of red rice germplasm, namely Mandel Handayani (from Gunungkidul), Segreng Handayani (from Gunungkidul). Gunungkidul is one of the regencies that become the germplasm of red rice. In Gunungkidul, there are two kinds of land in rice fields (wet) and dry land (gogo). Based on The Agriculture Office of Yogyakarta Special Region [21], in 2015 and 2016, the area of rice paddy harvest is

\footnotetext{
*Corresponding author: lestari@umy.ac.id
} 
14,936 and 15,205 ha, while the size of rice harvest fields is 42,078 and 41,344 Ku/ha. Gogo rice is one type of rice that is resistant and suitable for planting in dry land and used in some Kabupaten Gunungkidul. That is because gogo rice can grow and develop in a variety of soils, both paddy fields and dry land, then the type of soil does not affect the growth and development of gogo rice products [3].

In Gunungkidul Regency, especially in Kecamatan Ponjong has the highest productivity in the sub-district that grows red rice (Department of Agriculture and Food Gunungkidul Regency). Gunung kidul Regency is divided into three zones, namely the north, central and south zones. (Gunung Kidul Regency, Special Region of Yogyakarta: General Condition, Topography, 2015). Ponjong subdistrict is a special sub-district because it belongs to the three zones, namely the north, central and south zones. There are three villages chosen based on three zones, namely the northern zone (Umbulrejo village), the central zone (Sumbergiri village), and the southern zone (Sidorejo village). There are three villages chosen based on three zones, namely the northern zone (Umbulrejo village), the central zone (Sumbergiri village), and the southern zone (Sidorejo village). The north zone has hilly land and a type of latosol land. The central area has hilly land and gromosol land types. The southern site has the form of field or flat land and gromosol land type. Based on this, the use of inputs for red rice farming will vary and affect the production of red rice [4].

Table 1. Development of harvest area, production, and productivity of gogo rice plants

\begin{tabular}{|r|r|r|r|}
\hline Year & Harvest Area (Ha) & Production (Ton) & Productivity (Ku/Ha) \\
\hline 2014 & 3,537 & $15,521.75$ & 43.88 \\
\hline 2015 & 3,455 & $15,730.25$ & 45.53 \\
\hline 2016 & 3,447 & $12,835.42$ & 37.24 \\
\hline 2017 & 3,285 & $15,295.59$ & 46.56 \\
\hline 2018 & 3,417 & $19,321.29$ & 56.54 \\
\hline
\end{tabular}

Table 1 can be known if the productivity of gogo rice in Ponjong Subdistrict in the last five years has fluctuated. By Table 1 in 2014 and 2015, productivity increased, but in 2015In 2016, productivity decreased while land area increased. although rice Gogo at the year 2018 be productivity highest for five years last that is 5.65 tons per Hectares, productivity still more low Than with Varieties rice Gogo in the Park technology agriculture Pacitan (TPP) get achieved Productivity 6 tons per Hectares.

Efforts are made to improve the productivity of red rice, i.e., seed/seed varieties, labor needs, and water supply. In red rice in the dry land, the seed production factor used is the seed variety segreng (local variety Gunungkidul) resistant to drought and planting time until a short harvest of about 75 days. Varieties of segreng seeds have been used by farmers for generations; this variety began to be used around the $1900 \mathrm{~s}$. This seed variety has a slightly harder texture, and its productivity is 4-5 tons per ha. It weighs heavier compared to other types. Fertilizers used vary, ranging from organic fertilizers to foliage and inorganic fertilizers.

In addition, other production factors in dryland red rice are the labor needs on dry land and the availability of minimal water in dryland that only relies on rainwater even if the rain is only once a year. The farming of red rice can only be done once a year or earlier during the growing season [5]. The condition of the social characteristics of farmers, namely from the farmer himself such as, the age of farmers that varies from young to old age, the length of time farmers pursue the education of farmers who also go among others elementary school; Junior High School; High School/Vocational School; Bachelor, the 
experience of farming farmers varies from a year to decades. In addition, there are different zones, namely the north, central and south zones. The characteristic conditions of farmers and zone differences are included in the technical inefficiency factor [6]. Based on the problem, the problem formulation in this study is what factors affect the production of red rice farming? How significant level of technical efficiency for red rice farming and factors that affect the technical inefficiency of red rice in Gunung Kidul Regency?

\section{Method}

The population in this study used the purposive method because Ponjong sub-district has the highest productivity in Ponjong sub-district that grows red rice. After all, the Ponjong subdistrict is included in three zones: the north, central, and south zones. The population is taken from three villages, namely Umbulrejo Village (northern zone), Sumbergiri Village (central site), and Sidorejo Village (southern area), which has 399 farmers. From 399 farmers sampling that the sample becomes 200 farmers. Selection in each village is taken from the farmer group Sedyomulyo, Tani Maju, Sedyorukun, which samples in each farmer group use proportionally so that the samples are 66,56 , and 78 respectively.

Data taken from this study includes primary and secondary data. The primary source is data directly obtained from red rice farmers in Umbulrejo, Sumbergiri, and Sidorejo villages. Data collection techniques by interview and questionnaire. The required data include farmer profile (name, age, education level, farming experience), land area, production factors (seeds, fertilizers, pesticides, labor), production amount, and production selling price. Secondary sources are data sources that are not directly obtained, such as the agriculture and livestock departments of Gunungkidul, sub-districts, agencies, and institutions related to research. Secondary data include area, population, topographical state, geographical location, and agricultural state in the place chosen by the researcher. This research was conducted assuming the production of red rice is considered sold all, and there is no climate change. As well as limiting the problem, the data used is data in the last planting season in 2019.

Analysis of red rice farming in Ponjong Subdistrict used technical efficiency determination analysis with Stochastic Frontier Analysis (SFA) model [7] The stochastic Frontier Analysis (SFA) model used in this study is using the following equations:

$$
\operatorname{Ln} Y=\operatorname{Ln} \alpha+b_{1} \operatorname{Ln} X_{1}+b_{2} \operatorname{Ln} X_{2}+b_{3} \operatorname{Ln} X_{3}+b_{4} \operatorname{Ln} X_{4}+b_{5} \operatorname{Ln} X_{5}+b_{6} \operatorname{Ln} X_{6}+b_{7} \operatorname{Ln} X_{7}+v i-u i
$$

Information:

$\mathrm{Y}=$ Red rice production $(\mathrm{kg}), \alpha=$ Constants, $\mathrm{b}_{1}-\mathrm{b}_{7}=$ Regression coefficient, $\mathrm{X}_{1}=$ Land area $\left(\mathrm{m}^{2}\right), \mathrm{X}_{2}=$ Seed $(\mathrm{kg}), \mathrm{X}_{3}=$ Manure $(\mathrm{kg}), \mathrm{X}_{4}=$ Phonska Fertilizer $(\mathrm{kg}), \mathrm{X}_{5}=$ Urea Fertilizer $(\mathrm{kg}), \mathrm{X}_{6}=$ Chemical pesticides $(\mathrm{kg}) \mathrm{X}_{7}=$ Labor $(\mathrm{HKO}) \mathrm{v}_{\mathrm{i}}=$ Error (disturbanceterm) $\mathrm{ui}=$ Inefficiencies effect that appears

The next stage is to calculate the technical efficiency of red rice farming with the mathematical formula:

$$
T E_{i}=\frac{\mathrm{Yi}}{\mathrm{Yi} *}
$$

Information:

$\mathrm{TE}_{\mathrm{i}} \quad=$ Technical efficiency of farmers to $\mathrm{i}$ with a value between 0 and 1

$\mathrm{Y}_{\mathrm{i}} \quad=$ Output produced by farmers to $\mathrm{i}$ 
$\mathrm{Y} \quad=$ Potential output

In general, technical value efficiency in farmers ranges from zero to one or TEi value of $0 \leq \mathrm{TEi} \leq 1$. The efficiency index value $\geq$ is 0.7 , red rice farming is technically efficient $[8,9]$.

The next stage is to see the influence of farmer characteristics to use the function of production and technical in-efficiency factors, with the equation:

$$
u i=\delta_{0}+\delta_{1} Z_{1}+\delta_{2} Z_{2}+\delta_{3} Z_{3}+\delta_{4} Z_{4}+\delta_{5} Z_{5}
$$

$\mathrm{Z}_{1} \quad=$ Farmer's Age (year)

$\mathrm{Z}_{2} \quad=$ Duration of Formal Education (year)

$\mathrm{Z}_{3} \quad=$ Farmer's Experience of farming red rice (years)

$\mathrm{Z}_{4} \quad=$ Dummy of the northern zone $(\mathrm{D}=1$ if in the northern zone area and $\mathrm{D}=$

0 if in the other zone area)

$\mathrm{Z}_{5} \quad=$ Dummy of the south zone $(\mathrm{D}=1$ if in the southern zone area and

$\mathrm{D}=0$ if in the other zone area)

Estimation of Technical Efficiency and Technical Inefficiency Factor using a model function of the stochastic frontier equation with frontier application 4.1 and tested feasibility model using MLE (maximum likelihood) [10].

\section{Results and Discussion}

\subsection{Production and use of red rice farming production factors}

The use of production factors will affect the yield of farming and the level of efficiency. The number of inputs calculated in this study is used in one growing season or one planting period in 2019. The inputs used by red rice farmers are seeds, phonska fertilizer, urea fertilizer, manure, liquid pesticides, and labor.

Table 2. Production and use of factors of red rice farming production

\begin{tabular}{|l|r|r|r|r|r|r|r|}
\hline \multirow{2}{*}{ variable } & \multicolumn{2}{|c|}{ Northern Zone } & \multicolumn{2}{c|}{ Central Zone } & \multicolumn{2}{c|}{ South Zone } & \multicolumn{1}{c|}{$\begin{array}{c}\text { Recommended } \\
\text { Dosage }\end{array}$} \\
\cline { 2 - 8 } & Average & \multicolumn{1}{|c|}{ Per ha } & Average & Per ha & Average & Per ha & Per ha \\
\hline $\begin{array}{l}\text { Production } \\
(\mathrm{kg})\end{array}$ & 250.04 & $2,227.06$ & 372.46 & 2599.62 & 841.94 & 4.589 .21 & $4,680.00^{*}$ \\
\hline $\begin{array}{l}\text { Land Size } \\
\left(\mathrm{m}^{2}\right)\end{array}$ & $1,122.73$ & $10,000.00$ & $1,432.73$ & $10,000.00$ & $1,834.62$ & $10,000.00$ & $10,000.00$ \\
\hline Seed $(\mathrm{kg})$ & 8.77 & 78.14 & 6.86 & 47.86 & 10.66 & 58.11 & 45.00 \\
\hline Manure $(\mathrm{kg})$ & 614.77 & $5,475.71$ & 703.13 & $4,907.58$ & 812.24 & $4,427.32$ & $3,000.00$ \\
\hline $\begin{array}{l}\text { Phonska } \\
(\mathrm{kg})\end{array}$ & 42.42 & 377.87 & 28.93 & 201.91 & 48.54 & 264.57 & 150.00 \\
\hline Urea $(\mathrm{kg})$ & 53.89 & 480.03 & 69.02 & 481.72 & 80.83 & 440.60 & 200.00 \\
\hline PC (ml) & 34.09 & 303.64 & 22.32 & 155.80 & 3.67 & 19.99 & 180.00 \\
\hline $\begin{array}{l}\text { Kindergarten } \\
(\text { HKO) }\end{array}$ & 35.42 & 315.49 & 50.72 & 354.04 & 43.67 & 232.78 & 860.00 \\
\hline
\end{tabular}

$*$ = national potential DIY figures

Table 2 shows the productivity of each zone which is the northern zone of 2.23 tons per hectare; the central zone is 2.59 tons per ha. and the southern zone is 4.59 tons per hectare. 
The southern zone is close to reaching the DIY national productivity potential figure 4.68 tons per ha. However, the central and northern zones are still quite far from the national productivity figures. That is due to differences in the adoption of farmer technology. such as inputs and farmers' ability to apply cultivation technology.

The northern zone is the zone that uses the most seeds, which is $78.14 \mathrm{~kg}$ per hectare far enough of the recommended $45 \mathrm{~kg} / \mathrm{ha}$. That is due to the planting distance and the number of seeds planted in each hole. The recommended planting distance is $(30 \times 30) \mathrm{cm}$ or $(40 \times 40)$ $\mathrm{cm}$. with a legowo jajar system, and the number of seeds in each hole is 1-3 seeds. While in the northern zone, the planting distance is $10 \times 15 \mathrm{~cm}$ by using seeds $4-6$ on each hole. That is because farmers put seeds in the hole by manual means by hand. and the farmer never counts the seeds that fall in each hole. The use of more seeds than recommended is due to the habit of farmers who use their production seeds that have lower sprout power. So, when farmers use the labeled sources and good quality, then farmers will get used to using the standard measure used in seeds

The most widely used seed varieties are segreng handayani varieties, and some farmers use 24 inpari varieties. Variety of segreng handayani are much in demand to be grown by farmers because the price is lower than the varieties inpari 24 which is IDR 80,000.00 every $5 \mathrm{~kg}$ and seeds resistant to pests, diseases. In addition, seeds that are resistant to drought and suitable to be planted in dryland or moors. Varieties of segreng handayani have also been cultivated for generations by farmers. and seeds were obtained from the appropriation of Mr. Suharto around 1990.

Table 2 shows the use of manure in each zone. the northern zone $5475.71 \mathrm{~kg} / \mathrm{ha}$; the central zone $4907.58 \mathrm{~kg} / \mathrm{ha}$; and the southern zone $4427.32 \mathrm{~kg} / \mathrm{ha}$. The use of manure exceeds the recommendation of $3000 \mathrm{~kg} / \mathrm{ha}$. Manure used by farmers is made from livestock manure, cattle, and goats which almost every farmer has livestock. So, farmers in the use of manure depend on how much manure is owned. In addition to using manure, farmers use inorganic fertilizers to help grow and add nutrients to the soil. Inorganic fertilizers used by farmers in all three zones are phonska fertilizer and urea fertilizer. Phonska fertilizer as recommended is $150 \mathrm{~kg} / \mathrm{ha}$ and urea fertilizer are $200 \mathrm{~kg} / \mathrm{ha}$. The use of chemical fertilizers in all three zones is more than the recommended limit. Phonska fertilizer contains elements N (Nitrogen). P (Phosphor). K (Potassium) as much as 15\%, while urea fertilizer contains elements $\mathrm{N}$ as much as $46 \%$. Both fertilizers are in demand by farmers because phonska fertilizer increases the seeds' weight, strengthens the stem so that it does not collapse, and increases the resistance of plants to pest and disease attacks. While urea increases fertility and element $\mathrm{N}$ to help plants add green substances (chlorophyll), plants will be easier to do photosynthesis, accelerate growth. and increase the number of rice grains [11].

In addition to using chemical fertilizers to eradicate pests, 17 percent of farmers use chemical pesticides. Chemical pesticides are often used liquid pesticides with trade label dencis, which cost IDR 30,000 to $50 \mathrm{ml}$. As recommended, dencis is approximately $6 \mathrm{ml}$. used for one spray tank with water containing 14 liters. The average farmer sprays three times for one season, meaning it takes three tanks. So, the recommendation is $18 \mathrm{ml}$. for $1000 \mathrm{~m}^{2}$ and $180 \mathrm{ml}$ per ha. Based on Table 2 farmers exceed the limits of pesticide use. but some farmers use pesticides following the recommendations. Other farmers 83 percent farmers chose not to use chemical pesticides because they do not feel objections if there are pests and prefer to reduce the number of pesticides by manual means not with pesticides because more farmers consume their red rice.

In all three zones labor input on red rice farming is the total use of labor ranging from land preparation to harvesting. Entire labor is a workforce derived from families and outside family labor whose size is uniformed with HKO (People's Workday) units. The 
recommended force is $860 \mathrm{HKO}$ per ha. The use of labor in Table 2 shows less than recommended and it can be due to labor shortages in the family and fewer costs for out-offamily labor. Red rice farming, farmers allocate labor on land preparation activities land processing planting embroidery insect control weeding fertilization irrigation harvesting transportation and post-harvest.

\subsection{Stochastic Frontier Analysis Production Function}

The variables in this study were analyzed using the stochastic frontier production function that contains bound variables, namely red rice production (Y) and independent variables, namely land area (X1), seed (X2), manure (X3), phonska fertilizer (X4), urea fertilizer (X5), chemical pesticide (X6), and labor (X7). The labor that is considered is the labor used to prepare seedlings until the post-harvest process. When suspecting the production function all input variables that are thought to affect the production of red rice will be included in the model. Based on the testing of bound and free variables we will obtain the estimated production functions results from the Maximum Likelihood Estimation method.

Table 3. Cobb-Douglas Production Function Estimation Results with Stochastic Frontier Approach.

\begin{tabular}{|c|l|r|r|r|r|}
\hline No. & variable & Parameters & \multicolumn{1}{c|}{ Coefficient } & standard-error & \multicolumn{1}{c|}{ t-ratio } \\
\hline 1 & constant & $\beta_{0}$ & $11.12557 * * *$ & 0.3044650 & 7.9130467 \\
\hline 2 & Land & $\beta_{1}$ & $-0.0000082^{* * *}$ & 0.0000013 & -6.2588950 \\
\hline 3 & seed & $\beta_{2}$ & $0.3999463^{* * *}$ & 0.0535293 & 7.4715431 \\
\hline 4 & Manure & $\beta_{3}$ & $-0.0000061^{* * *}$ & 0.0000021 & -2.9108997 \\
\hline 5 & $\begin{array}{l}\text { Phonska } \\
\text { Fertilizer }\end{array}$ & $\beta_{4}$ & $0.4138355^{* * *}$ & 0.0706437 & 5.8580681 \\
\hline 6 & $\begin{array}{l}\text { Urea } \\
\text { Fertilizer }\end{array}$ & $\beta_{5}$ & $0.0000042^{* * *}$ & 0.0000015 & 2.7401653 \\
\hline 7 & $\begin{array}{l}\text { Liquid } \\
\text { Pesticides }\end{array}$ & $\beta_{6}$ & $0.0281013^{*}$ & 0.0167179 & 1.6809141 \\
\hline 8 & workforce & $\beta_{7}$ & $0.0000004^{* * *}$ & 0.0000001 & 3.9122720 \\
\hline Sigma-squared $\left(\sigma^{2}\right)$ & & 1.2800497 & 2.3185474 & 0.5520912 \\
\hline Gamma $(\gamma)$ & $0.8287300^{* * *}$ & 0.3076619 & 2.6936389 \\
\hline \multicolumn{2}{|l|}{ OLS log likelihood } & -151.6886400 & \\
\hline log-likelihood MLE & -148.3539100 \\
\hline
\end{tabular}

Description:

: significantly affect the $\alpha$ rate of $1 \%$

*: significant effect on the $\alpha$ rate of $10 \%$

Based on the results of the estimates in Table 3, it is known that the log-likelihood MLE -151.68 has a more excellent value compared to the log-likelihood OLS value -148.35 . It means that the production function with the MLE method obtained is a good value and can describe the condition of the field. It is the same with [12] that the value of log-likelihood in the production function needs to be well noticed whether the suspect model the value of log-likelihood with MLE method is 20.43 and more significant than the log like the value of a function with OLS method of 14.48. Therefore, the production function with this MLE method is already good and according to the field conditions. In addition, sigma-squared has a value of 1.28 which means greater than zero, such as research from, which has sigmasquared 1.131 . 
The technical efficiency analysis of red rice production contributed by the technical inefficiency factor of red rice production in this study was confirmed through gamma, which is 0.823 . which is $5 \%$ alpha Gamma $5 \%$ with a yield of 0.823 means 82 percentage variation in output from red rice farmers there is a difference of technical efficiency in each farmer and the remaining $18 \%$ caused by external influences such as climate, pest attacks, and diseases. Therefore, the result of technical inefficiencies has a real effect on the variability of red rice production.

Table 3 shows that of the overall variables included in the model, there are seven variables with a significant rate of $1 \%$ and there is one variable with a significant rate of $10 \%$. That is the variable has a real effect on the production of red rice. The value of the variable coefficient is divided into two namely positive and negative, where the negative value indicates the tendency of real variables (significant variables) to decrease the production of red rice. Meanwhile, if the value is positive there is a real variable tendency (significant variable) to increase the production of red rice. Constants show significant value at a confidence level of $99 \%$ meaning that if farmers do not use production factors or production factors $(0)$ then red rice production of $11.12557 \mathrm{~kg}$ at a confidence level of $99 \%$.

The variable land area has a real effect on the production of red rice with an error rate of $1 \%$ but has a negative coefficient value. The negative value indicates that the increase in land area by $1 \%$ and if other factors remain. it will reduce the production of red rice by $0.0000082 \%$ at a confidence level of $99 \%$. It is in line with [14] research on a variable land area of negative value which means that smaller land area has greater technical efficiency.

In this study the value of negative correlation can occur due to low land management. Farmers at the time of managing the land are still complex and slow due to hilly land, moorland, and terraced land. Slow land processing such as in piracy using tractors not all farmers can use tractor engines because of the location that is not possible. The site is hilly; the area has a small plot of land and scattered. If there is an increase in the land area will cause farmers difficulty to cultivate the land. In addition, there are still farmers who use intercropping or mixed systems in the northern and central zones while in the southern zone there are farmers who use the monoculture system. In addition, irrigation in the south zone uses bur wells so that water availability for red rice farming is sufficient and can maximize production. While the northern and central zones do not have wells and only use irrigation rain fed rice fields. So, production is not maximal.

Seeds have a real influence on the production of red rice and have a positive coefficient value. If seed use is added $1 \%$, and other variables remain, then there will be a production increase of $0.399 \%$ at a confidence level of $99 \%$. It is the same with [15] where, seeds have a real effect on semi-organic rice production at a confidence level of $90 \%$, which means that each seed input addition by $10 \%$, assuming ceteris paribus will increase semi-organic rice production by the value of seed input elasticity, which is $1.80 \%$. The northern seed zone used for one hectare is $78.14 \mathrm{~kg}$ : in the central zone, the use of seeds is $47.86 \mathrm{~kg} / \mathrm{ha}$, and the southern zone of seed use is $58.11 \mathrm{~kg} / \mathrm{ha}$, while the recommended dose according to PPL is $45 \mathrm{~kg} / \mathrm{ha}$. The conditions in the field of seed use exceed the use of recommendations. but the addition of seeds by $1 \%$ can still increase production. In addition to showing that seeds are very influential on farming production, determine whether the production of red rice will be good or not, and the productivity level.

The variable manure has a real effect on the production of red rice with an error rate of $1 \%$ but has a negative coefficient value. The negative value indicates that adding manure by $1 \%$ and other factors remaining will reduce red rice production by $0.0000061 \%$ a confidence level of $99 \%$. The southern zone of manure use for one hectare is $5475.71 \mathrm{~kg}$; in the middle zone uses manure weighing $4907.58 \mathrm{~kg} / \mathrm{ha}$ and the southern zone uses manure 
weighing $4427.32 \mathrm{~kg} / \mathrm{ha}$, while the recommended dose according to PPL is $3000 \mathrm{~kg} / \mathrm{ha}$ for manure.

The quality of manure in all three zones has an uneven quality of maturity. On one hand, there is manure whose maturity is appropriate and the maturity is not proper. Manure that has not matched its maturity has not been able to provide benefits or the development of plants. Farmers use all the manure owned both dry manure and that is still wet. Therefore, can suspect excessive use of manure and uneven quality of reducing the production of red rice.

The use of manure in all three zones has exceeded the recommended limit, thus, reducing production. If too much manure is given, it will cause the plant to collapse because the stem is not strong enough to hold a lot of seeds. The seeds have fallen out first before reaching the farmer's place. It is different from [15] where the variable manure has a positive value and a real effect. Increasing the use of manure by $1 \%$ will increase organic rice production by $0.046 \%$ with a confidence level of $99 \%$.

Fonseka fertilizer has a real influence on the production of red rice and has a positive coefficient value. If the use of phonska fertilizer is added $1 \%$ and other variables remain. then there will be an increase in production by $0.414 \%$. at a confidence level of $99 \%$. The northern zone of phonska fertilizer use for one hectare is $377.87 \mathrm{~kg}$. The central zone is $201.91 \mathrm{~kg} / \mathrm{ha}$ for phonska fertilizer and the southern zone uses $264.57 \mathrm{~kg} / \mathrm{ha}$ in the use of phonska fertilizer while the recommended dose according to PPL is $150 \mathrm{~kg} / \mathrm{ha}$. The use of phonska fertilizer in all three zones exceeds the recommendations but is still limited to rational. Suppose added phonska fertilizer will affect the production of red rice. This soil still needs elements $\mathrm{N}, \mathrm{P}$, and $\mathrm{K}$ as much as $15 \%$ each in the content of fertilizer phonska. It is the same with the research [16] which on the variable fertilizer NPK-Phonska has a real influence on rice production and has a positive value with an error rate of $1 \%$. then every addition of fertilizer phonska $1 \%$ and other variables remain then there will be an increase in production by $0.0261 \%$ at the level of trust $99 \%$.

Urea fertilizer has a real influence on the production of red rice and has a positive coefficient value. If the use of urea fertilizer plus $1 \%$ and other variables remain, then there will be an increase in production by $0.0000042 \%$ at a confidence level of $99 \%$. The northern zone of urea fertilizer use is $480.03 \mathrm{~kg} / \mathrm{ha}$ in the central zone urea fertilizer weighs $481.72 \mathrm{~kg} / \mathrm{ha}$. The southern zone uses urea fertilizer considering $440.60 \mathrm{~kg} / \mathrm{ha}$. In comparison, the recommended dose by PPL is $200 \mathrm{~kg} / \mathrm{ha}$ for urea fertilizer. The use of urea fertilizer in all three zones exceeds the recommendations. However, it is still limited to rational so that urea fertilizer will affect the production of red rice. This soil still needs an $\mathrm{N}$ element of $46 \%$ in urea fertilizer content. The result is the same as [17] addition of urea fertilizer by $1 \%$ and other variables will increase corn production by $0.071 \%$.

Chemical liquid pesticides have a real influence on the production of red rice and have a positive coefficient value. If the use of liquid chemical pesticides plus $1 \%$ and other variables remains, there will be an increase in production by $0.028 \%$. at a confidence level of $99 \%$. The northern zone of using chemical liquid pesticides for one hectare is $303.64 \mathrm{ml}$. in the central zone uses chemical liquid pesticides as much as $155.80 \mathrm{ml} / \mathrm{ha}$. The southern zone uses $19.99 \mathrm{ml} /$ ha of chemical liquid pesticides, while the recommended dose by PPL is $180 \mathrm{ml} / \mathrm{ha}$. The use of chemical liquid pesticides only uses a few pesticides from all three zones. If increased use of pesticides can still be tolerated to kill pests and increase productivity. This is inversely proportional to the research [13] on the variable chemical liquid pesticide has no real effect on rice production. with a positive coefficient value.

Labor has a real influence on the production of red rice and has a positive coefficient value. If labor use is increased by $1 \%$, and other variables remain, there will be a production increase of $0.0000004 \%$, at a confidence level of $99 \%$. Increasing the use of 
labor can increase productivity, but with a small value, farmers rarely add to the labor because it will increase costs. This is in line with [18] on the technical efficiency of corn farming in Turban District which explains that labor positively affects corn production with a coefficient value of 0.39 at a $10 \%$ error rate.

\subsection{Technical Efficiency of Red Rice Farming}

Red rice farming in Ponjong sub-district can be said to be efficient if it can produce maximum output by using a certain number of inputs. The level and spread of technical efficiency can be known from the calculation of the Frontier 4.1 program, with a level of technical efficiency that has a value between 0.000 to 1.000 . Analysis of the technical efficiency level of red rice aims to find out the highest efficiency and lowest efficiency as well as rat-average efficiency achieved by farmers in farming. The level of technical efficiency achieved by farmers indicates a difference in the level of mastery and application of technology and management of agriculture.

Table 4. Technical efficiency level in red rice farming

\begin{tabular}{|l|r|r|}
\hline Description & Number of Farmers & Percentage (\%) \\
\hline$<0.500$ & 3 & 1.5 \\
\hline $0.501-0.600$ & 2 & 1 \\
\hline $0.601-0.700$ & 6 & 3 \\
\hline $0.701-0.800$ & 28 & 14 \\
\hline $0.801-0.900$ & 144 & 72 \\
\hline $0.901-1.00$ & 17 & 8.5 \\
\hline Total & 200 & 100.0 \\
\hline Minimun efficiency value & 0.302 & \\
\hline Maximum efficiency value & 0.920 & \\
\hline Average Technical Efficiency Value & 0.837 & \\
\hline
\end{tabular}

Based on Table 4, it has an average technical efficiency value of red rice which is 0.837 , with a minimum value of 0.302 and a maximum value of 0.920 . That is means that red rice farming has been technically efficient because the value exceeds 0.7. Like Gultom research.. et al. (2016) that value of technical efficiency exists at $0<\mathrm{ET}<1$, meaning the value of technical efficiency of farmers $>0.7$ means efficient. but if the value of efficiency of farmers' technology $\leq 0.7$ means not efficient. That shows that red rice farming has been efficient even though it has not been evenly distributed; farmers can still raise the value of technical efficiency to $16.3 \%$. Improving technical efficiency can be done with farming management, such as adding inputs that affect red rice farming. The same research from [19] has an average technical efficiency of 0.768 ; this shows that, in general, farmers still have the opportunity to increase rice production by $24.2 \%$ to achieve maximum production.

As a result of the efficiency level, according to Table 4, there are still 11 farmers who are not technically efficient by $5.5 \%$. Efficient farmers reached 189 farmers with a percentage of $94.5 \%$. According to [20]. there are differences between inefficient and inefficient farmers due to land tenure, inputs, the application of technology, and internal factors such as age, education, farming experience, and zone differences. Farmers tend to have efficiency with a range of $0.7-0.92$. First, farmers with $94.5 \%$ use the recommended seed varieties, namely segreng handayani seeds with seeds $8.6 \mathrm{~kg}$. The two land areas used by farmers have an average of $1411 \mathrm{~m}^{2}$ which has a small area and is more optimal in land 
tenure. The three workers used by farmers had an average of 42.5 fewer farmers compared to the overall average sample.

\subsection{Technical Inefficiency Factors of Red Rice Farming}

The results of the analysis of the technical efficiency of red rice in table 4 showed that in the frontier model, the minimum value of technical efficiency was $30.2 \%$. The subject is thought to be due to the internal factors of farmers' social characteristics, which were used as technical inefficiencies in this study. Technical inefficiency factors include age. Education, the experience of farming red rice, and differences in regional zones. The effect of technical inefficiencies can be analyzed together using frontier 4.1 with the MLE method, and the results can be seen in Table 5 .

Table 5. Factors influencing technical inefficiency in red rice farming in Ponjong Subdistrict.

\begin{tabular}{|c|l|c|r|r|r|r|}
\hline No. & \multicolumn{1}{|c|}{ variable } & Parameters & coefficient & & $\begin{array}{c}\text { Standard- } \\
\text { error }\end{array}$ & t count \\
\hline 1 & constant & $\delta_{0}$ & -4.723977 & $\mathrm{Ns}$ & 13.095904 & -0.360722 \\
\hline 2 & age & $\delta_{1}$ & 0.316957 & $\mathrm{Ns}$ & 0.752308 & 0.421312 \\
\hline 3 & Formal education & $\delta_{2}$ & 0.000113 & $\mathrm{Ns}$ & 0.000278 & 0.407328 \\
\hline 4 & Farming Experience & $\delta_{3}$ & 0.020585 & $\mathrm{Ns}$ & 0.102154 & 0.201507 \\
\hline 5 & Dummy zone north & $\delta_{4}$ & -0.000008 & $\mathrm{Ns}$ & 0.000023 & -0.357141 \\
\hline 6 & Dummy zone south & $\delta_{5}$ & 0.355692 & $\mathrm{Ns}$ & 0.927952 & 0.383309 \\
\hline
\end{tabular}

Description: $\mathrm{ns}=$ non-significant

The results of the estimation in Table 5 shows there are no significant internal factors of farmers. However, there is a tendency for each variable can increase or decrease technical inefficiencies. A variable that has a negative value is a dummy of the northern zone, while the other variable is positive. Coefficients on age variables show positive values and have no noticeable effect on technical inefficiencies. It means that the older the farmer's ages. the more inefficient it is because the physical strength is reduced. So, processing the land is less optimal. Similar research also occurred in [22] age factor shows positive and insignificant value means that the older the farmer's age the lower their workability and technical ability and negative impact on technical efficiency. Older farmers find it harder to accept and use better technology.

The higher the education the higher the output produced and the right input which means the technical efficiency is also high. However, in the statistics the coefficient on variable education farmers showed a positive value and had no noticeable effect on technical inefficiencies. Research aligned is research [20] on educational variables that do not affect technical efficiency a positive and insignificant value. It means that education does not cause changes in technical efficiency and technical efficiency does not respond to changes in education. It can happen because informal education is not explained about the material technically cultivation of red rice knowledge about the cultivation of red rice obtained from years of experience.

The higher one's experience, the higher the knowledge, which will make it easier for farmers to allocate inputs. Coefficients on the variable experience of farming red rice showed a positive value and had no noticeable effect on technical inefficiencies. Farmers' knowledge of cultivation is gained from years of experience. 
It follows the prediction results although the coefficient value is not significant, it shows a positive value. It means that the longer it takes to farm brown rice, the less efficient it is because older farmers have more experience so that in cultivating the land. it is less than optimal. The experience of farmers in the range of 19-36 years has the highest efficiency rate, in line with the increasing age of farmers.

In contrast to the research of on the positive and significant farming experience variable at an error rate of $1 \%$. It can see that farmers' knowledge of cultivation techniques is mainly obtained from years of experience [25].

Dummy north zone coefficient value is negative but not significant. It means that in the dummy the northern zone contributes to technical inefficiencies or affects technical efficiency but not in real terms. The Dummy south zone has a positive and insignificant coefficient value. It means that the dummy of the southern zone does not contribute to the effect of technical inefficiency or has no impact on technical efficiency. The difference in land type and the region's state in the northern zone whose land is moored, hilly, and rarely water have a lower percentage value than in the central and southern zones. The central and southern zones have a higher percentage of $96.43 \%$ and $98.72 \%$ of efficient farmers. In addition, lime can fertilize the soil to increase production in the southern zone. The availability of water in the central and northern zones uses a rainfed rice field while there are irrigation canal wells in the southern zone. The north zone of the land is latosol and hilly in the central zone, the soil is gromosol and hilly and in the southern zone the land is grumosol and airy.

\section{Conclusions}

The study results concluded that the production factors of land area, seeds, manure, phonska fertilizer,urea fertilizer liquid pesticides and labor significantly affect production. Red rice farmers in Gunung Kidul Regency have been technically efficient with an average technical efficiency of 0.837 . Internal factors of farmers such as age, length of formal education, the experience of farming brown rice and area (zone) have no significant effect on technical inefficiency.

Increased production can also be done by increasing the use of seeds with high productivity, increasing the use of phonska fertilizer urea fertilizer liquid pesticides as recommended and increasing the use of a competent workforce. And the need for processing manure with an appropriate maturity level can positively affect red rice production. The northern and central zones should use well irrigation to maintain water availability and increase production

\section{Reference}

1. S. D. Indrasari. B. Besar. and P. Tanaman. Iptek Tanam. Pangan 2. 227 (2007).

2. P. al K. Dwinita W.Utami. Kristamtini. 20. 10 (2009).

3. 4P. W. M. M. T. S. E. Widiyanti. Agrista J. Ilm. Mhs. Agribisnis UNS 3. (2015).

4. N. A. Eko. Haryono \& Tjahyo. Pengantar Geomorfologi Da Hidrologi Karst (Yogyakarta. Fakultas Geografi. Unibersitas Gadjah Mada. 2004).

5. L. Rahayu. E. Febriana. and E. Istiyanti. in IOP Conf. Ser. Earth Environ. Sci. (2020).

6. Y. Khotimah. E. Antriyandarti. and S. Supardi. Appl. Ecol. Environ. Res (2019).

7. M. N. Hasnain. M. E. Hossain. and M. K. Islam. Am. J. ... (2015). 
8. E. Istiyanti. L. Rahayu. and Sriyadi. Int. Food Res. J. 25. (2018).

9. L. Rahayu and D. Febriani. in E3S Web Conf. (2021).

10. G. E. Coelli. T. J.. Rao. D.S.P.. \& Battese. An Introduction to Efficiency Analysis. (1998).

11. S. GAO. J. GAO. W. CAO. C. ZOU. J. Huang. J. BAI. and .... J. Integr. ... (2018).

12. L. Gultom. R. Winandi. and S. Jahroh. 7 (2014).

13. B. Yoko. Y. Syaukat. and A. Fariyanti. J. Agribisnis Indones. 2. 127 (2017).

14. O. Boubacar. Z. Hui-qiu. M. A. Rana. and S. Ghazanfar. J. Northeast Agric. Univ. (English Ed. 23. 67 (2016).

15. K. Murniati. J. H. Mulyo. I. Irham. and S. Hartono. J. Penelit. Pertan. Terap. 14. 31 (2017).

16. M. Fauzan. AGRIMOR (2020).

17. A. Y. Fadwiwati. S. Hartoyo. S. U. Kuncoro. and I. W. Rusastra. J. Agro Ekon. 32. 1 (2016).

18. M. A. Maryanto. K. Sukiyono. and B. Sigit Priyono. Agrar. J. Agribus. Rural Dev. Res. 4. 1 (2018).

19. T. Triyono. J. Handoyo Mulyo. M. Masyhuri. and J. Jamhari. Agrar. J. Agribus. Rural Dev. Res. 2. 1 (2016).

20. I. M. Ningsih. R. Dwiastuti. and S. Suhartini. J. Manaj. Dan Agribisnis 12. 216 (2015).

21. Dinas Pertanian Daerah Istimewa Yogyakarta: Statistik Tanaman Pangan. (2016). 